\title{
Obtaining Stem Cell Spheroids from Foreskin Tissue and the Effect of Corchorus olitorius L. on Spheroid Proliferation
}

\section{Sünnet Derisinden Kök Hücre Sferoidlerinin Elde Edilmesi ve Corchorus olitorius L.'nin Sferoid Proliferasyonuna Etkisi}

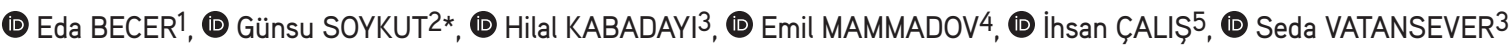 \\ ${ }^{1}$ Near East University Faculty of Pharmacy, Department of Biochemistry, Nicosia, North Cyprus \\ 2Near East University Faculty of Health Sciences, Department of Nutrition and Dietetics, Nicosia, North Cyprus \\ 3 Manisa Celal Bayar University Faculty of Medicine, Department of Histology and Embryology, Manisa, Turkey \\ ${ }^{4}$ Near East University, Faculty of Medicine, Department of Pediatric Surgery, Nicosia, North Cyprus \\ 5 Near East University Faculty of Pharmacy, Department of Pharmacognosy, Nicosia, North Cyprus
}

\begin{abstract}
Objectives: Mesenchymal stem cells are self-renewing stem cells. The human foreskin has potential to be used as a source of stem cells. The aim of the study was to obtain spheroid formation of human foreskin cells (hnFSSCs) isolated from newborn human foreskin tissue. In addition, the apoptotic and proliferative effects of a traditional plant, Corchorus olitorius L. (C. olitorius), on hnFSSC spheroids were investigated.

Materials and Methods: After a routine circumcision procedure the cells were isolated and cultured in suitable medium. The plant leaves was extracted with ethanol and their composition was analyzed by liquid chromatography coupled with mass spectrometry (LC-MS/MS). The foreskin stem cells were characterized immunocytochemically by CD45, CD34, and CD90 antibodies. hnFSSC spheroids were formed using the hanging drop technique. Immunofluorescence staining was used on the obtained spheroids to determine the distribution of caspase-3 and Ki-67 after being treated with C. olitorius extract for $48 \mathrm{~h}$.

Results: Immunostaining analysis showed that hnFSSCs were positive for CD45 and CD34 and negative for CD90. According to LC-MS/MS C. olitorius was rich in flavanols and hydrocinnamic acid derivatives. Although the spheroids obtained were loose and floating, the cells interacted with each other. Caspase-3 activity was higher in the control group than in the extract-treated group and Ki-67 was higher in the extract-treated group than in the control group, suggesting that the plant might have the capacity to increase stem cell proliferation due to its rich polyphenolic content. Conclusion: The results suggest that hnFSSCs and spheroids might be used in stem cell generation, tissue repair and renewal as human foreskin tissue has potential to be used as a stem cell source. C. olitorius also increased proliferation of hnFSSCs, showing that polyphenols might increase proliferation of stem cells.
\end{abstract}

Key words: Corchorus olitorius, spheroid, human foreskin, stem cell

ÖZ

Amaç: Mezenkimal kök hücreler kendi kendini yenileyebilme özelliğine sahiptir. Sünnet derisinin kök hücre kaynağı olarak kullanılma potansiyeli vardır. Çalışmanın amacı, yeni doğmuş insan sünnet derisi izole hücrelerinden (hnFSSCs) sferoid oluşumunu elde etmektir. Buna ek olarak, Kıbrıs'a özgü geleneksel bir bitki olan Corchorus olitorius L. (C. olitorius) bitkisinin hnFSSCs sferoidleri üzerindeki apoptotik ve proliferatif etkileri de araştırılmıştır.

Gereç ve Yöntemler: Rutin sünnet prosedüründen sonra hücreler izole edildi ve uygun besi yeri ortamında kültüre edildi. Bitki yaprakları etanol ile ekstre edildi ve içerik analizi sıvı kromatografi-kütle spektrometresi (LC-MS/MS) yöntemi ile yapıldı. Sünnet derisi kök hücreleri CD45, CD34, CD90 antikorları kullanılarak immünositokimyasal olarak karakterize edilmiştir. hnFSSC sferoidleri asılı damla tekniği kullanılarak oluşturuldu. Elde edilen sferoidler daha sonra $C$. olitorius ekstraktı ile 48 saat süre muamele edildikten sonra kaspaz-3 ve Ki-67'nin dağıtımı için immünofloresan boyama yöntemiyle boyandı.

*Correspondence: E-mail: gunsusoykut@gmail.com, Phone: +90542 8660880 ORCID-ID: orcid.org/0000-0002-8479-1457

Received: 28.09.2018, Accepted: 07.03.2019

OTurk J Pharm Sci, Published by Galenos Publishing House. 
Bulgular: İmmünoboyama analiz sonuçları, hnFSSC'lerin CD45, CD34 için pozitif fakat CD90 için negatif olduğunu gösterdi. LC-MS/MS sonuçlarına göre C. olitorius bitkisinin, flavanoller ve hidro-sinnamik asit türevleri içerdiği saptanmıştır. Elde edilen sferoidler gevşek ve yüzer vaziyette olmalarına rağmen hücreler birbirleri ile etkileşim halindeydi. Kaspaz-3 aktivitesi kontrol grubunda ekstrakt grubuna göre daha yüksekti ve ekstraksiyon uygulanan grupta Ki-67 aktivitesi kontrol grubuna göre daha yüksek bulundu. Bu sonuçlar, bitkinin polifenol içeriğinden dolayı kök hücre proliferasyonunu artırma kapasitesine sahip olabileceğini göstermektedir.

Sonuç: hnFSSC'lerin ve sferoidlerin kök hücre üretimi ve doku onarımı ve yenilenmesinin bir parçası olarak kullanılabilme potansiyeli, sünnet derisinin kök hücre kaynağı olarak kullanılması durumunda mevcuttur. C. olitorius içerdiği polifenollerinden dolayı kök hücrelerin proliferasyonunu artıran etki göstermeyi başarmıștır.

Anahtar kelimeler: Corchorus olitorius, sferoid, sünnet derisi, kök hücre

\section{INTRODUCTION}

Mesenchymal stem cells (MSCs) are multipotent, self-renewing adult stem cells that are isolated from multiple tissues such as adipose tissue, bone, umbilical cords, dental pulp, and skin. MSCs are fibroblast-like cells and in vitro studies have shown that they have the potential to differentiate into adipocytes, osteoblasts, and chondrocytes. According to the International Society of Cellular Therapy criteria, human MSCs are defined by positive expression for cell surface markers including CD29, CD44, CD90, CD49a-f, CD51, CD73 (SH3), CD105 (SH2), CD106, CD166, and Stro-1 and lack of expression of CD45, CD34, CD14 or CD11b, CD79a or CD19, and HLA-DR surface molecules. ${ }^{2}$ Because of their easy isolation and lack of ethical issues, MSCs are among the first stem cell types to be used in the treatment of various conditions, including autoimmune diseases, orthopedic injuries, and liver and cardiovascular diseases. ${ }^{3}$

Skin is the largest organ of the human body and a source of multipotent mesenchymal cells with the capacity for multipotential differentiation. Human newborn foreskin tissue is part of the skin that is obtained by noninvasive techniques and can proliferate without cell differentiation over a long period. ${ }^{4}$ Recent studies reported that human foreskin isolated cells (hnFSSCs) have stem cell properties and multipotent and pluripotent abilities. Skrzypczyk et al. ${ }^{5}$ showed that storage of hnFSSCs and newborn foreskin tissue might be very beneficial in terms of disease development potentials and treatment actions.

Spheroids are 3D cell culture models to be used as in vitro models for screening new anticancer therapeutics. There are multiple methods for spheroid creation, namely hanging drop, spinner culture, nonadhesive hydrogel micromolds, pellet culture, liquid overlay, rotating wall vessel, external force, cell sheets, and microfluidics. ${ }^{6}$ 3D spheroids models have been shown to be advantageous compared to traditional two dimensional (2D) cell culture. 2D monolayer culture mostly focuses on cell growth conditions, cell proliferation, and gene and protein expression profiles. However, 3D spheroids are able to accurately mimic some properties of normal or tumor tissue structure, such as their micro-environments, spatial architecture, physiological responses, signaling cascades, gene expression patterns, and drug resistance mechanisms. Thus, the behavior of 3D cultured cells is more reflective of in vivo cellular responses. ${ }^{7}$

Corchorus olitorius L. (C. olitorius) is a plant that is commonly consumed in Eastern Mediterranean and Middle Eastern countries. The plant is known to have medicinal properties, showing anti-inflammatory, anticancer, antibacterial, and antioxidant effects. ${ }^{8-11}$ It is also known that the plant content is rich in polyphenols, antioxidant vitamins, and minerals that are part of endogenous antioxidant systems. ${ }^{8,9,12} \mathrm{C}$. olitorius contains quercetin and its derivatives and chlorogenic acid derivatives, which are thought to provide the plant with its medicinal properties., ${ }^{9,13}$ Polyphenols also tend to improve proliferation and have the potential to increase stem cell viability due to differentiation in stem cells. ${ }^{14,15}$

The aim of the present study was to obtain spheroid formation of hnFSSCs isolated from newborn human foreskin tissue. Furthermore, the proliferative and apoptotic effects of $C$. olitorius on hnFSSC spheroids were assessed.

\section{MATERIALS AND METHODS}

\section{Isolation and culture of human foreskin stem cells}

Human newborn foreskin tissue was obtained following routine circumcisions. Foreskin samples were obtained from donors 4 to 40 weeks of age at Near East University Hospital after informed consent was obtained from their parents. The study was approved by Near East University Health Sciences Ethics Committee (YDU/2018/62-658). The mucosa part of the foreskin was collected. The mucosa was digested enzymatically with $1 \mathrm{mg} / \mathrm{mL}$ collagenase type 1 (Sigma, C0130) for $1 \mathrm{~h}$ at $37{ }^{\circ} \mathrm{C}$ and $5 \% \mathrm{CO}_{2}$. Cells were collected and centrifuged to remove collagenase. The hnFSSCs were cultured in DMEM-F12 medium supplemented with $10 \%$ fetal bovine serum, $1 \%$ penicillinstreptomycin, and $25 \mu \mathrm{g} / \mathrm{mL}$ amphotericin B in a humidified atmosphere at $37{ }^{\circ} \mathrm{C}$ and $5 \% \mathrm{CO}_{2}$. When the cultured cells reached $80 \%$ confluence state, they were subcultured using $0.25 \%$ trypsin-EDTA solution (Biochrom, $L$ 2143) for further studies.

\section{Characterization of human foreskin stem cells}

hnFSSCs were characterized immunocytochemically for distribution of CD45, CD34, and CD90 (Thy-1 glycoprotein). The hnFSSCs were fixed with $4 \%$ paraformaldehyde in phosphate buffered saline (PBS) at $4{ }^{\circ} \mathrm{C}$ for $30 \mathrm{~min}$. For permeabilization, $0.1 \%$ Tween 20 (Sigma-Aldrich) was added for 15 min on ice. The cells were washed with PBS and endogenous peroxidase activity was quenched by incubation with $3 \% \mathrm{H}_{2} \mathrm{O}_{2}$ for 5 min at room temperature. After the cells were washed with PBS three times for $5 \mathrm{~min}$, primary antibodies anti-CD45 (sc-1178), anti-CD34 (sc-74499), and anti-CD90 (Thy-1 glycoprotein) (sc19614) were added, followed by incubation overnight at $4{ }^{\circ} \mathrm{C}$. 
Biotinylated secondary antibody and streptavidin-peroxidase (Histostain-Plus, IHC Kit, HRP, 859043, Thermo Fischer) were added and each secondary antibody was incubated for $30 \mathrm{~min}$ followed by PBS wash $(\times 3)$ for $5 \mathrm{~min}$. Cells were then stained with diaminobenzidine for $5 \mathrm{~min}$ for enhancement of immunolabeling. After being washed with distilled water, they were counterstained with Mayer's hematoxylin for 5 min and mounted with mounting medium (Merck Millipore, 107961, Germany). All specimens were examined under a light microscope (Olympus BX40, Tokyo, Japan).

\section{Plant material and extraction}

Mature C. olitorius leaves were collected from Kyrenia, Cyprus. The collected plant sample was registered with the Near East Herbarium at Near East University under the Herbarium number 6904. The dry leaves of C. olitorius (100 g) were powdered (Waring Commercial Blender, USA) and extracted with $80 \%$ ethanol during incubation overnight at room temperature with occasional stirring. The extract was vacuum filtered and concentrated to $200 \mathrm{~mL}$ by rotary evaporator (BUCHI Rotavapor R-210). The extract was evaporated and lyophilized (Christ Alpha 1-4 LD Plus, Germany) to yield $14.8 \mathrm{~g}$ of crude extract.

Liquid chromatography-mass spectrometry (LC-MS/MS) analysis of $C$. olitorius leaf extract

The extract composition of $C$. olitorius leaves was investigated by LC/MS-MS analysis. LC separation was performed using an Agilent 1200 high performance LC (HPLC) system (Agilent, USA) equipped with an automatic degasser, a quaternary pump, and an autosampler. Chromatographic separation was carried out on a Waters SunFire ${ }^{\mathrm{TM}} \mathrm{C} 18$ column $(150 \mathrm{~mm} \times 4.6 \mathrm{~mm}, 5 \mathrm{~m})$ at $40{ }^{\circ} \mathrm{C}$. The flow rate of the mobile phase was maintained at 0.5 $\mathrm{mL} / \mathrm{min}$. The mobile phases were $(A)$ acetonitrile:water:formic acid (10:89:1, v/v/v) and (B) acetonitrile:water:formic acid (89:10:1, v/v/v). The HPLC system was connected to a $3200 \mathrm{Q}$ TRAP LC/MS/MS system with a hybrid triple quadrupole/LIT (linear ion trap) mass spectrometer equipped with an ESI ion source (Applied Biosystems/MDS Sciex, USA). The instrument control and data acquisition were carried out by the software Analyst 1.6.

\section{Cell viability and growth assay}

The extract was dissolved with dimethyl sulfoxide [(DMSO), Sigma-Aldrich)] to $100 \mathrm{mg} / \mathrm{mL}$. It was further diluted in culture medium $(5 \mu \mathrm{g} / \mathrm{mL}, 10 \mu \mathrm{g} / \mathrm{mL}, 20 \mu \mathrm{g} / \mathrm{mL}, 50 \mu \mathrm{g} / \mathrm{mL}$, and $100 \mu \mathrm{g} /$ $\mathrm{mL}$ ). The final concentration of DMSO in cell lines was less than $0.05 \%$. hnFSSCs were collected, suspended in medium, and seeded in 96 well culture dishes at a density of $5 \times 10^{4} / \mathrm{mL}$ cells in each well with $100 \mu \mathrm{L}$ of medium. The hnFSSCs were incubated for $24 \mathrm{~h}$ and $48 \mathrm{~h}$.

Cell viability was estimated by MTT assay. MTT solution (Biotium, \#30006) was heated to $37{ }^{\circ} \mathrm{C}$ and then $10 \mu \mathrm{L}$ was added to each well. After $4 \mathrm{~h}$ incubation at $37^{\circ} \mathrm{C}$ in $5 \% \mathrm{CO}_{2^{\prime}}$ $200 \mu \mathrm{L}$ of DMSO was added to dissolve the formazan salts. The absorbance was measured at $570 \mathrm{~nm}$ with a spectrophotometer (Versa Max, Molecular Device, Sunnyvale, CA, USA).
Preparation of the $3 D$ spheroid model and determination of the effects of $C$. olitorius leaf extract

hnFSSC spheroids were formed using the hanging drop technique with 600 cells per $20 \mu \mathrm{L}$ droplet (Y5, Fermenne 2013). The cells were incubated in a humidified atmosphere at $37{ }^{\circ} \mathrm{C}$ in $5 \% \mathrm{CO}_{2}$ for $36 \mathrm{~h}$ and $72 \mathrm{~h}$. Two different culture time spheroids were collected and transferred in two different 24 well plates and all of them were incubated with $50 \mu \mathrm{g} / \mathrm{mL} \mathrm{C}$. olitorius extract for $48 \mathrm{~h}$.

\section{Immunofluorescence of $3 D$ spheroids}

The spheroids were fixed with $4 \%$ paraformaldehyde at room temperature for $30 \mathrm{~min}$ and then washed three times with PBS. The spheroids were then embedded in OCT compound (Jung, 0201-08926) and cross-sectioned with a cryostat at 8 $\mu \mathrm{m}$ thickness. Sections were kept at $-20{ }^{\circ} \mathrm{C}$ until the staining procedure. The sections were warmed at room temperature overnight and washed with PBS for $2 \times 30 \mathrm{~min}$ at $37^{\circ} \mathrm{C}$. The sections were traced around with a PAP pen (Diagnostic BioSystems, KO39). The blocking solution [10\% sheep serum (sc-2488) in PBS with 0.05\% Triton X-100)] was added, followed by incubation for $1 \mathrm{~h}$. The blocking solution was aspirated and primary antibodies [rabbit polyclonal anti-caspase-3 (sc98785) and mouse monoclonal anti-Ki-67 (BioGenex mv370uc)] diluted in $2 \%$ sheep serum in PBS with $0.05 \%$ Triton X-100 were added overnight in a humidified chamber at $4{ }^{\circ} \mathrm{C}$. The cells were then incubated with secondary antibodies (goat anti-rabbit TRITC sc-2091, goat anti-mouse FITC Millipore AP308F) for 2 $h$ after washing with PBS with $0.05 \%$ Triton X-100. They were then washed and stained with DAPI (Applichem A1001-0025) for 2 min. All sections were covered with mounting media (JA1750) and then evaluated under a fluorescence microscope (Olympus IX71, Tokyo, Japan).

Staining of Ki-67 and caspase-3 was also graded semiquantitatively using the intensity of staining with a value of 1,2 , or 3 (mild, moderate, or strong, respectively).

\section{Statistical analysis}

The results were analyzed using GraphPad Prism 7 software. The results were expressed as mean \pm standard deviation and standard error where appropriate.

\section{RESULTS}

\section{Cell morphology}

Fibroblast-like and spindle-formed cells were isolated from the mucosal part of human newborn foreskin tissue. After 4 days, fibroblast-homologous, spindle-formed morphology cells were visible and it had been observed that the cells covered the surface after 7 days. After subculture of the cells, the proliferation rate was triggered and accelerated (Figure 1).

Immunocytochemical characterization of human foreskin stem cells Immunostaining analysis showed that the hnFSSCs were positive for CD45 and CD34 and negative for CD90. Mucosaderived foreskin fibroblast-like stromal cells expressed MSC surface markers at passage 1 (Figure 2). 


\section{LC-MS/MS Analysis of C. olitorius extract}

The extract of $C$. olitorius was analyzed by LC-MS/MS. Caffeoyl glucose, 3-caffeoylquinic acid, quercetin glucoside, quercetin acetylglucoside, 3,5-dicaffeoylquinic acid, 1,3-dicaffeoylquinic acid, luteolin, and/or kaempferol acetylglucoside were identified in C. olitorius extract (Table 1).

\section{Cell viability and cytotoxicity}

The hnFSSCs were treated with different concentrations (5$100 \mu \mathrm{g} / \mathrm{mL}$ ) of $C$. olitorius extract for 24 and $48 \mathrm{~h}$. None of the dilutions showed any cytotoxic effects on the hnFSSCs and 50 $\mu \mathrm{g} / \mathrm{mL}$ concentration at $48 \mathrm{~h}$ incubation period was optimal as cell viability was $100 \%$ (Figure 3 ).

\section{Effects of C. olitorius extract on the $3 D$ culture hnFSSC spheroids model}

The cells started to aggregate after $24 \mathrm{~h}$ (Figure 4). After 36 and $72 \mathrm{~h}$, two different groups of spheroids were collected and placed in 6 well plates. The clumps increased in size with time until day 7 and started to disintegrate after 7 days of incubation. Day 7 was therefore chosen as the time for collecting the spheroids for assays.

Immunoreactivity of caspase-3 was detected in both the control and extract-treated groups. However, the intensity of caspase- 3 was less in the extract-treated group than in the

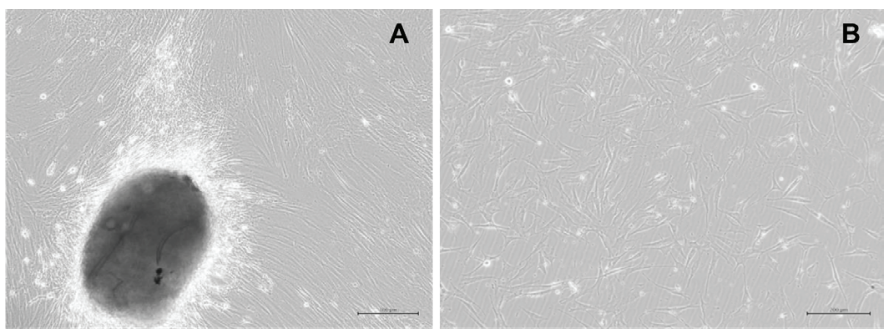

Figure 1. hnFSSCs. (A) Basal photomicrographic representation of cells on day 4 of isolation. (B) Mucosa-derived hnFSSC morphologies at passage 1. scale bars $=200 \mu \mathrm{M}$

hnFSSCs: Human newborn foreskin stem cells
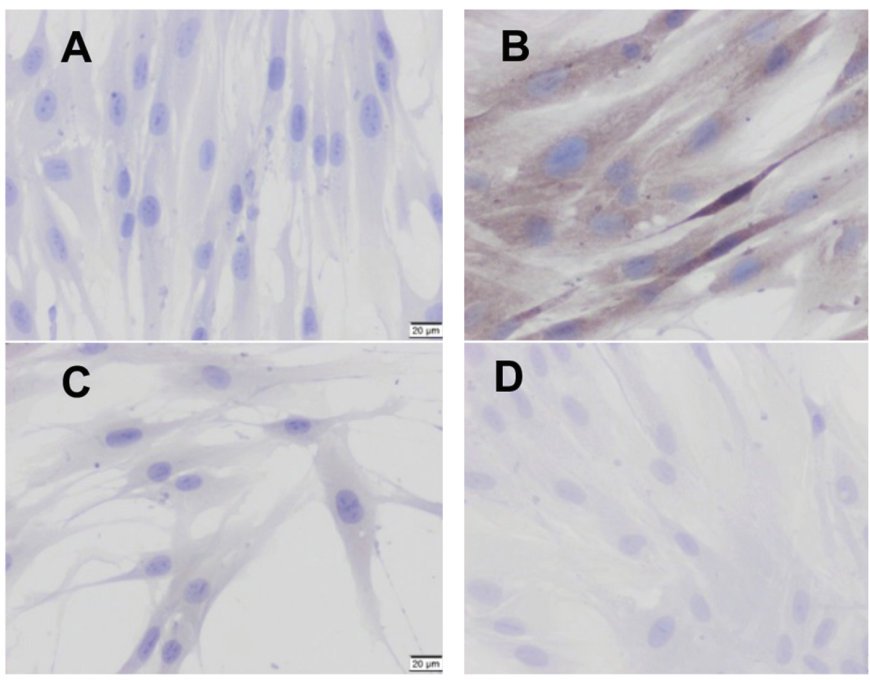

D

Figure 2. Immunochemical staining indicated the positive mesenchymal stem cell surface markers CD45 and CD34 and negative for CD90. Negative control (A), CD45 (B), CD34 (C), CD90 (D). Scale bars $=20 \mu \mathrm{M}$ control group (Table 2). Immunoreactivity of caspase-3 was higher in the 36-h-incubated control group than in the extracttreated spheroid group (Figure 5). Immunostaining intensity

\begin{tabular}{llll}
\multicolumn{4}{l}{ Table } \\
Rt & Main identified components of Corchorus olitorius extract \\
\hline 4.1 & 341 & 179,161 & Identified as \\
\hline 4.7 & 353 & 191,179 & Caffeoyl glucose \\
\hline 9.9 & 463 & $299,271,255$ & 3-Caffeoylquinic acid \\
\hline 10.9 & 505 & $299,271,255$ & Quercetin glucoside \\
\hline 11.5 & 515 & $353,191,179,173$ & 3,5-Dicaffeoylquinic acid \\
\hline 12.1 & 515 & $353,191,179,135$ & 1,3-Dicaffeoylquinic acid \\
\hline 12.6 & 489 & $284,255,227$ & $\begin{array}{l}\text { Luteolin/kaempferol } \\
\text { acetylglucoside }\end{array}$ \\
\hline
\end{tabular}

$\begin{aligned} & \text { Table 2. The intensity of caspase-3 and Ki-67 immunolabeling in } \\
& \text { hnFSSC spheroids treated with Corchorus olitorius extract at } 50 \\
& \mu \mathrm{g} / \mathrm{mL} \text { concentration for } 36 \text { and } 72 \mathrm{~h}\end{aligned}$
$\begin{aligned} & \text { Corchorus } \\
& \text { olitorius extract } \\
& \text { group }\end{aligned}$
\begin{tabular}{llllll}
$36 \mathrm{~h}$ & $72 \mathrm{~h}$ & $36 \mathrm{~h}$ & $72 \mathrm{~h}$ \\
\hline Caspase-3 & + & ++ & ++ & ++ \\
\hline Ki-67 & ++ & +++ & + & - \\
\hline
\end{tabular}

hnFSSC: Human newborn foreskin stem cell

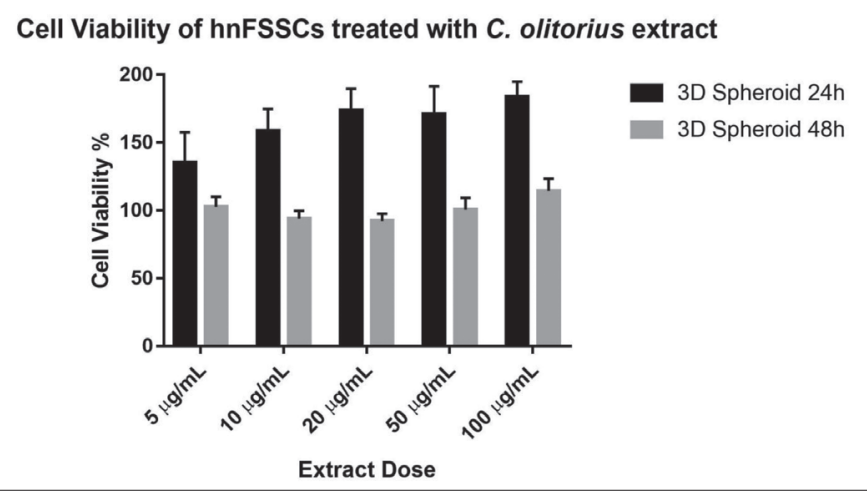

Figure 3. Effect of Corchorus olitorius extract on cell viability of hnFSSCs. The data are given as mean \pm standard deviation hnFSSCs: Human newborn foreskin stem cells
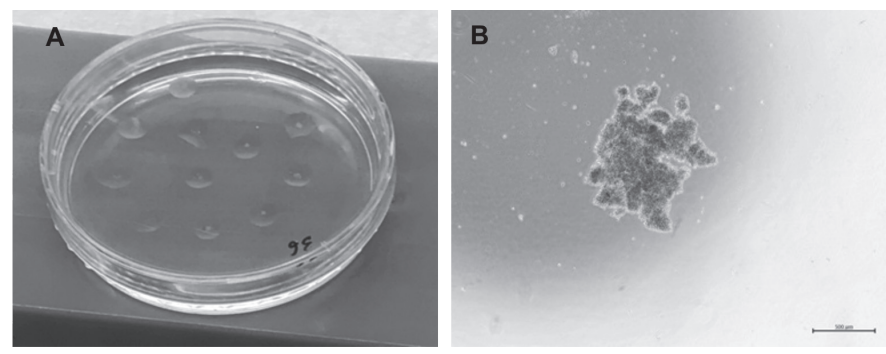

Figure 4. (A) Hanging drops ( 600 cells/20 $\mu$ ) on the lid of a petri dish, (B) 7 day incubated spheroid. Scale bars $=500 \mu \mathrm{M}$ 
for $\mathrm{Ki}-67$ was moderate to strong for spheroids treated with extracts for 36 and 72 h (Table 2). As shown in Figure 6, Ki-67 immunoreactivity was weak or negative in the control groups (Figure 6).

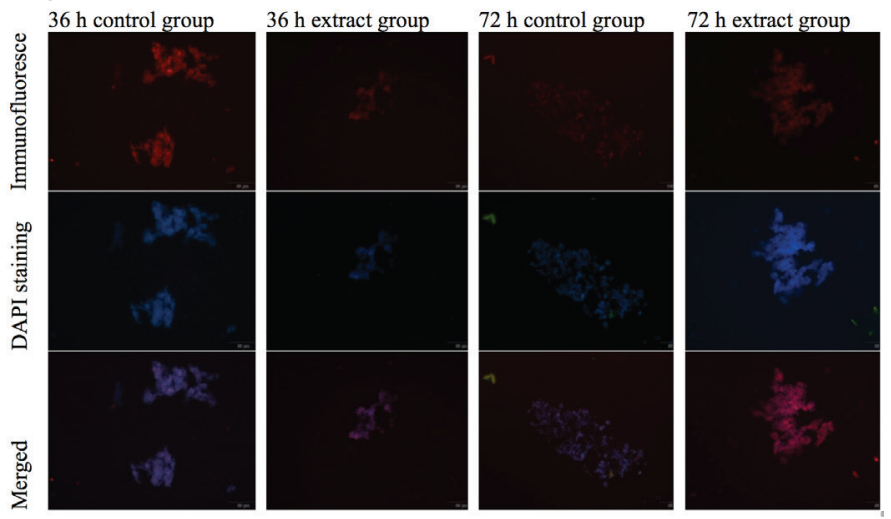

Figure 5. Immunofluorescence, DAPI staining, and merged photomicrographs of caspase- 3 in 36 and $72 \mathrm{~h} \mathrm{hnFSSC}$ spheroids treated with $50 \mu \mathrm{g} / \mathrm{mL}$ Corchorus olitorius extract for $48 \mathrm{~h}$. Scale bars $=50 \mu \mathrm{M}$ hnFSSC: Human newborn foreskin stem cell

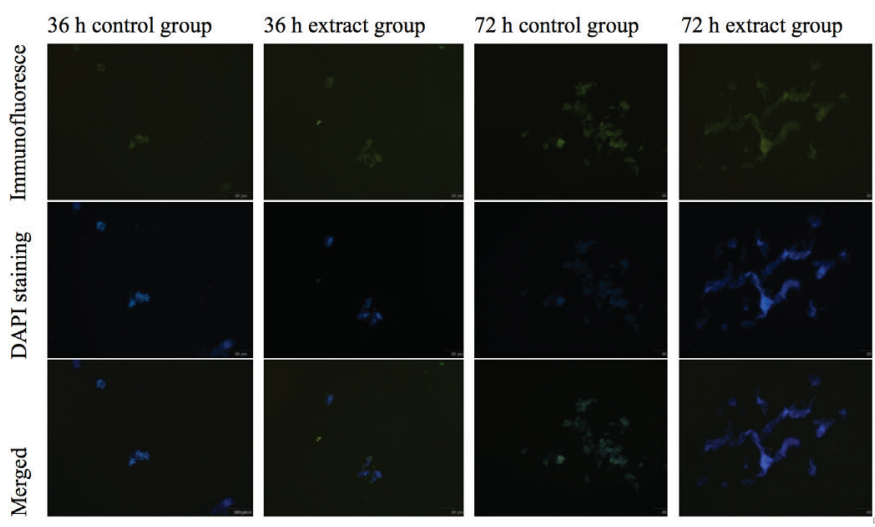

Figure 6. Immunofluorescence, DAPI staining, and merged photomicrographs of $\mathrm{Ki}-67$ in 36 and $72 \mathrm{~h}$ hnFSSC spheroids treated with $50 \mu \mathrm{g} / \mathrm{mL}$ Corchorus olitorius extract for $48 \mathrm{~h}$. Scale bars $=50 \mu \mathrm{M}$ hnFSSC: Human newborn foreskin stem cell

\section{DISCUSSION}

Circumcision is a ritual that has been performed for centuries for medical, cultural, or religious reasons. The foreskin removed after surgery is usually discarded. It has been thought that the foreskin tissue might have the potential to be used as a source of stem cells, especially if the procedure is performed in early infancy and the tissue is collected from newborns. ${ }^{4}$ The foreskin is usually more easily accessible than other tissues used for stem cell generation. In addition, as the tissue is usually discarded straight after the procedure, subjection to ethical issues might be negligible in terms of stem cell collection. If the collected foreskin tissue is from newborns, the differentiation rate and capacity are higher than in adults and nearly as high as in bone marrow. ${ }^{4}$ Most studies' results suggested that hnFSSCs therapy is more beneficial than adult and embryonic stem cell therapies. The fact that positive markers were shown for hemopoietic and neural stem cells is also an indication that foreskin stem cells might be used in treatments for blood cancers, Parkinson's and Alzheimer's.' A very similar study found that hnFSSCs can also differentiate in myogenic cells. ${ }^{3}$ In parallel to these studies, our results also revealed that hnFSSCs expressed MSC markers. In the current study, hnFSSCs positively expressed CD45 and CD34, which are known to be MSC surface markers. However, CD90 expression was negative. This might have been due to the hnFSSCs collected having originated from mucosal cells. Our results suggested that hnFSSCs are capable of differentiating into MSCs and have potential to be used in tissue renewal and repair.

MSCs play an important role in repairing damaged tissue through their anti-inflammatory properties. Recent studies showed that 3D spheroids of MSCs have high differentiation ability and cell survival when compared with 2D culture. Moreover, 3D MSCs' spheroid structure increases the anti-inflammatory proteins from immune cells. ${ }^{15}$ MSC spheroids are widely used in oncology research as they synthesize more extracellular matrix than 2D culture. 3D culture also increases the therapeutic effects of intervention when compared with 2D formation. ${ }^{12}$ MSC spheroids are solid aggregates due to upregulated cadherin expression. ${ }^{16}$ In our study, hnFSSC spheroids were formed using the hanging drop technique. Our results showed that spheroids collected from hnFSSCs were not as compact as MSC spheroids. We obtained more loose and floating spheroids from hnFSSCs. However, even though the spheroid structure was loose, the cells were intact and interacted with each other.

In the current study, the apoptotic and proliferative effects of the plant $C$. olitorius on spheroids were studied. Caspase- 3 is known as an executioner caspase and its trigger induces apoptosis, programmed cell death..$^{17}$ On the other hand, expression of $\mathrm{Ki}-67$ is an indication of cell proliferation. ${ }^{18}$ Caspase- 3 immunostaining was observed in both cell groups, but this was expected in spheroid structures as the center is more compact and the nutrients are harder to diffuse to the center. However, caspase-3 staining intensity was less in extracttreated cells, which shows the plant might prevent stem cell apoptosis. In contrast to these results, Ki-67 immunostaining was higher in extract-treated cells than in the control group in both incubation periods, which indicates that $C$. olitorius might have the capacity to increase stem cell proliferation. The LCMS/MS results indicated that $C$. olitorius contains polyphenolic compounds including quercetin and caffeoylquinic acid and their derivatives. Other studies also showed similar results, showing that the plant is rich in flavonols and hydroxycinnamic acids. ${ }^{9,10}$ A $50 \mu \mathrm{g} / \mathrm{mL}$ dose was regarded as the treatment and optimal dose for further immunofluorescence analysis. In addition, other studies also stated that the plant has apoptotic effects in cancer cell lines via caspase-3 activation. ${ }^{19}$ On the other hand, quercetin glucuronide has been shown to increase neural stem cell proliferation and promote migration. ${ }^{20}$ Another study showed that quercetin enhanced bone marrow MSC proliferation and osteogenic differentiation. ${ }^{21}$ This indicates that C. olitorius has the potential to increase stem cell proliferation by its rich polyphenolic content, which might be supportive for stem cell differentiation and better for mimicking in vivo structures and further tissue repair. 


\section{Study limitations}

Flow cytometry could help in the identification of stem cell sources. In addition, the use of Western blotting could enhance Ki-67 and caspase- 3 immunofluorescence staining results in terms of identification of protein expression of the antibodies.

\section{CONCLUSION}

In summary, the results indicate that hnFSSCs have great potential in stem cell differentiation and potential to be used in stem cell therapy. Moreover, spheroids were obtained from hnFSSCs and $C$. olitorius extract has the potential for enhancing their proliferation activity. All of these indicate that hnFSSCs and using spheroids may be used as a part of future clinical applications. These in vitro results also need to be evaluated with animal studies for further progression of hnFSSC spheroids in clinical applications.

\section{ACKNOWLEDGEMENTS}

The authors would like to thank the Experimental Health Research Center of Health Sciences laboratory.

Conflicts of interest: No conflict of interest was declared by the authors. The authors alone are responsible for the content and writing of the paper.

\section{REFERENCES}

1. Pittenger MF, Mackay AM, Beck SC, Jaiswal RK, Douglas R, Mosca JD, Moorman MA, Simonetti DW, Craig S, Marshak DR. Multilineage potential of adult human mesenchymal stem cells. Science. 1999;284:143-147.

2. Dominici M, Le Blanc K, Mueller I, Slaper-Cortenbach I, Marini FC, Krause DS, Deans RJ, Keating A, Prockop DJ, Horwitz EM. Minimal criteria for defining multipotent mesenchymal stromal cells. The International Society for Cellular Therapy position statement. Cytotherapy. 2006;8:315-317.

3. Squillaro T, Peluso G, Galderisi U. Clinical Trials With Mesenchymal Stem Cells: An Update. Cell Transplant. 2016;25:829-848.

4. Somuncu ÖS, Taşlı PN, Şişli HB, Somuncu S, Şahin F. Characterization and Differentiation of Stem Cells Isolated from Human Newborn Foreskin Tissue. Appl Biochem Biotechnol. 2015;177:1040-1054.

5. Skrzypczyk A, Giri S, Bader A. Generation of induced pluripotent stem cell line from foreskin fibroblasts. Stem Cell Res. 2016;17:572-575.

6. Foty R. A Simple Hanging Drop Cell Culture Protocol for Generation of 3D Spheroids. J Vis Exp. 2011:2720.

7. Ong CS, Zhou X, Han J, Huang CY, Nashed A, Khatri S, Mattson G, Fukunishi T, Zhang $\mathrm{H}$, Hibino N. In vivo therapeutic applications of cell spheroids. Biotechnol Adv. 2018;36:494-505.
8. Zeghichi S, Kallithraka S, Simopoulos AP. Nutritional Composition of Molokhiya (Corchorus olitorius) and Stamnagathi (Cichorium spinosum). In: Simopoulos AP, Gopalan C, eds. Karger: World Rev Nutr Diet; 2003:1-21.

9. Handoussa H, Hanafi R, Eddiasty I, El-Gendy ME, Khatib AE, Linscheid M, Mahran L, Ayoub N. Anti-inflammatory and cytotoxic activities of dietary phenolics isolated from Corchorus olitorius and Vitis vinifera. J Funct Foods. 2013;5:1204-1216.

10. Ihan S, Savaroğlu F, Çolak F. Antibacterial and Antifungal Activity of Corchours olitorius L. (Molokhia) Extracts. Int J Nat Eng Sci. 2007;1:5961.

11. Soykut G, Becer E, Calis I, Yucecan S, Vatansever S. Apoptotic effects of Corchorus olitorius L. leaf extracts in colon adenocarcinoma cell lines. Prog Nutr. 2018;20:689-698.

12. Azuma K, Nakayama M, Koshioka M, Ippoushi K, Yamaguchi Y, Kohata K, Yamauchi $\mathrm{Y}$, Ito $\mathrm{H}$, Higashio $\mathrm{H}$. Phenolic antioxidants from the leaves of Corchous Olitorius L. J Agric Food Chem 1999;47:3963-3966.

13. Darcansoy İșeri Ö, Yurtcu E, Sahin FI, Haberal M. Corchorus olitorius ( jute ) extract induced cytotoxicity and genotoxicity on human multiple myeloma cells ( ARH-77 ). Pharm Biol. 2013;51:766-770.

14. Yagi H, Tan J, Tuan RS. Polyphenols suppress hydrogen peroxideinduced oxidative stress in human bone-marrow derived mesenchymal stem cells. J Cell Biochem. 2013;114:1163-1173.

15. Safaeinejad Z, Kazeminasab F, Kiani-Esfahani A, Ghaedi K, NasrEsfahani MH. Multi-effects of Resveratrol on stem cell characteristics: Effective dose, time, cell culture conditions and cell type-specific responses of stem cells to Resveratrol. Eur J Med Chem. 2018;155:651657.

16. Lin RZ, Chou LF, Chien CCM, Chang HY. Dynamic analysis of hepatoma spheroid formation: Roles of $\mathrm{E}$-cadherin and beta1-integrin. Cell Tissue Res. 2006;324:411-422.

17. Huerta S, Goulet EJ, Livingston EH. Colon cancer and apoptosis. Am J Surg. 2006;191:517-526.

18. Scholzen T, Gerdes J. The Ki-67 protein: from the known and the unknown. J Cell Physiol. 2000;182:311-322.

19. Li CJ, Huang SY, Wu MY, Chen YC, Tsang SF, Chyuan JH, Hsu HY. Induction of apoptosis by ethanolic extract of Corchorus olitorius leaf in human hepatocellular carcinoma (HepG2) cells via a mitochondriadependent pathway. Molecules. 2012;17:9348-9360.

20. Baral S, Pariyar R, Kim J, Lee HS, Seo J. Quercetin-3-O-glucuronide promotes the proliferation and migration of neural stem cells. Neurobiol Aging. 2017;52:39-52.

21. Pang X, Cong Y, Bao NR, Li YG, Zhao JN. Quercetin stimulates bone marrow mesenchymal Stem Cell Differentiation through an Estrogen Receptor-Mediated Pathway. Biomed Res Int 2018:1-11. 